\title{
CITLIVOSTNÍ ANALÝZA SOFTWARU AREBA PRO SIMULACE PORUŠENÍ SYPANÝCH HRÁZÍ V DŮSLEDKU VNITŘNÍ EROZE
}

\author{
SENSITIVITY ANALYSIS OF THE SOFTWARE AREBA FOR \\ SIMULATION DAM BREACHING DUE TO INTERNAL EROSION
}

Stanislav Kotaška ${ }^{*}, 1$

*kotaska.s@fce.vutbr.cz

${ }^{1}$ Vysoké učení technické v Brně, Ústav vodních staveb, Veveří 331/95, 62000 Brno

\begin{abstract}
Abstrakt
Jednou z častých př́čin poruchy vodního díla je vnitřní eroze v tělese hráze. Pro simulaci těchto jevů je $\mathrm{k}$ dispozici řada softwarů umožňující výpočet porušení sypaných hrází v důsledku vnitřní eroze zemin. $V$ rámci příspěvku byl zvolen software (SW) A Rapid Embankment Breach Analysis (AREBA), pro který byla provedena jednocestná citlivostní analýza. Př́spěvek má za cíl pochopení klíčových geotechnických parametrů vstupujících do SW AREBA a jejich vliv na hydrogram odtoku, velikost průlomového otvoru a také na časové charakteristiky poruchy. Nejvíce citlivými parametry ovlivňující výstupy jsou drsnostní součinitel dle Manninga a koeficient erodibility. Tyto dva parametry by měli být variovány metodou Monte-Carlo v SW AREBA.
\end{abstract}

\section{Klíčová slova}

Citlivostní analýza, porušení, vnitřní eroze, AREBA

\begin{abstract}
One of the causes of earth fill dam failure are internal erosion. To simulate these phenomena, a number of software are available to calculate the failure of an earth fill dams due to overtopping or due to internal erosion. For this purpose, software (SW) A Rapid Embankment Breach Analysis (AREBA) was chosen, for which a one-way sensitivity analysis was performed. The paper aims to understand the key geotechnical parameters input to the SW AREBA and their influence on the dam breach hydrogram, the size of the breach and also on the time characteristics. The most sensitive parameters influencing the outputs are the Manning's roughness coefficient and the erodibility coefficient. These two parameters should be varied by the Monte-Carlo method in the AREBA.
\end{abstract}

\section{Key words}

Sensitivity analysis, dam-break, internal erosion, AREBA

\section{1 ÚVOD}

Součástí projektu IMPACT v roce 2012 bylo vytvoření SW AREBA - A Rapid Embankment Breach Analysis [8] pro rychlou predikci porušení homogenních sypaných hrází v důsledku vnitřní eroze a přelití s možností využití metody Monte-Carlo. SW AREBA byl vyvinut na základě předchozího softwaru HR BREACH, s kterým byl porovnáván a ověřen a validován na 4 historických porušeních hrází, 7 polních zkouškách a 18 laboratorních experimentech, ale pouze pro prrípad přelití. Validace SW AREBA pro príípad vnitřní eroze byla nepřesná kvůli špatnému vyhodnocení pokusu a parametrů zemin [8]. V roce 2014 byl zveřejněn dokument „Small Reservoirs Simplified Risk Assessment Methodology research report“ [3], kde bylo provedeno podrobnější testování SW AREBA z hlediska predikce porušení sypaných hrází v důsledku vnitřní eroze. Navržený př́stup zahrnoval analýzu poruchy za předpokladu nulového př́toku, malého objemu nádrže, vysoce erodovatelných materiálů a průsakové trubice s počátečním průměrem $0,5 \mathrm{~m}$. S výše popsanými předpoklady se hráz vždy protrhla $\mathrm{v}$ krátkém čase. Bližší analýza interaktivních účinkủ výběru různých pevností materiálu nebo počátečního průměru potrubí nebyla $\mathrm{v}$ rámci práce provedena. 


\section{POPIS SOFTWARU AREBA}

Uvedený SW AREBA je jednorozměrný matematický model vycházející z rovnice pro výtok otvorem nebo přepadu přes širokou korunu, kdy je úloha formulována jako 1D úloha v neznámé funkci $Q_{\mathrm{b}}(t)$. Jedná se o zjednodušený model pro rychlý výpočet a predikci hydrogramu průlomové vlny. Vstupní parametry do výpočtu je možné zadat pomocí rovnoměrného nebo normálního rozdělení, kdy volba jednotlivých parametrů je řešena pomocí metody Monte-Carlo s využitím Latin Hypercube Sampling (LHS).

\section{Výpočet průtoku}

\section{Transformace nádrže}

Při sestavení matematického modelu se používá zákon zachování hmotnosti vody protékající nádrží neboli vodohospodářská bilance nádrže ve tvaru:

$$
\frac{d V}{d t}=Q_{\text {in }}(t)-Q_{b}(H)-Q_{f}(H),
$$

kde $V$ je objem vody v nádrži $\left[\mathrm{m}^{3}\right] ; Q_{\text {in }}$ přítok vody do nádrže $\left[\mathrm{m}^{3} / \mathrm{s}\right] ; Q_{\mathrm{b}}$ průtok vody průlomovým otvorem $\left[\mathrm{m}^{3} / \mathrm{s}\right] ; Q_{\mathrm{f}}$ ostatní odtok vody z nádrže (přes přeliv, spodními výpustmi, nouzový přeliv) $\left[\mathrm{m}^{3} / \mathrm{s}\right] ; t$ čas $[\mathrm{s}] ; H$ poloha hladiny v nádrži [m n. m.]. Za předpokladu změny objemu:

$$
d V=A d H,
$$

kde $A$ je plocha hladiny v nádrži $\left[\mathrm{m}^{2}\right]$.

\section{Průtok průlomovým otvorem (průsakovou trubicí) v případě vnitřní eroze}

Otvor průsakové trubice je předpokládán jako kruhový. Průtok $Q_{\mathrm{b}}$ průsakovou trubicí je typicky řešen jako výtok otvorem v tlakovém režimu za předpokladu zanedbání ztrát na vtoku a výtoku jako [1], [8]:

$$
Q_{b}=\frac{1}{\sqrt{\alpha+\lambda \frac{L}{D_{p}}+\Sigma \zeta}} A \sqrt{2 g\left(H-H_{v y ́ t o k}\right)},
$$

kde $\alpha$ je Coriolisovo číslo; $L$ délka průsakové trubice $[\mathrm{m}] ; D_{\mathrm{p}}$ průměr průsakové trubice $[\mathrm{m}] ; A$ je průtočná

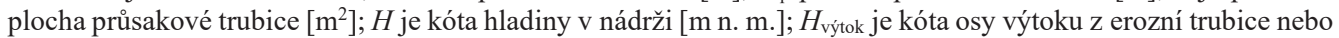
polohy hladiny $\mathrm{v}$ inundaci $\left[\mathrm{m} \mathrm{n}\right.$. m.], $\lambda$ je součinitel ztrát tření po délce $\left(\lambda=f\left(d_{50}\right)\right)[-]$ a $\zeta$ jsou ztráty místní (na vtoku a výtoku), které jsou zanedbávány [-].

\section{Průtok průlomovým otvorem v př́ípadě přelití}

Pro stanovení vztahu průtoku průlomovým otvorem v důsledku přelití, je průlomový otvor hráze reprezentován obdélníkem. Výpočet přelití je řešen pomocí přepadové rovnice přes širokou korunu, která byla modifikována pro př́pad porušení sypaných hrází v důsledku přelití $[6,8]$ pro obdélníkový profil jako:

$$
Q_{b}=c_{w} B h_{2} \sqrt{2 g\left(H-h_{2}\right)},
$$

kde B je šiřka přepadového paprsku [m], H je rozdíl hladiny vody v nádrži a dna průlomového otvoru u kterého se předpokládá že je ve výšce koruny hráze $[\mathrm{m}], h_{2}$ je hloubka v místě průlomového otvoru [m], kdy $h_{2} \approx d \approx$ $2 / 3 H$ a $c_{\mathrm{w}}$ je přepadový součinitel, který se je funkcí $\mathrm{H}$ atd.

\section{Eroze soudržného materiálu}

Počátek eroze při porušení sypané zemní hráze ze soudržného materiálu vznikne po překročení kritického tečného napětí $\tau_{\mathrm{c}}$. Pro posouzení vzniku eroze se provede výpočet tangenciálního či tečného napětí od proudící vody, který se posoudí s kritickým tečným napětím. Pokud je kritické tečné napětí překročeno nastává eroze zeminy. Při volbě kritického tečného napětí rozlišujeme zeminy soudržné a nesoudržné, povrch opevněný a neopevněný, a přihlížíme k vlastnostem zeminy.

\section{Tečné napětí}

Při proudění kapaliny v korytě či trubici se všechny částice (molekuly vody) nepohybují stejně. Č́stice, které jsou v blízkosti stěn se téměř nepohybují a částice vzdálenější od stěny se pohybují rychleji. Pro zjednodušení si tedy můžeme představit, že se kapalina skládá s tenkých souvislých vrstviček a všechny částice jedné vrstvy mají stejnou rychlost. Dvě sousední vrstvy se oproti sobě pohybují různou rychlostí. Uvnitř kapaliny a na rozhraní kapaliny a materiálu tedy vzniká tř̌ení. V tomto případě se vnitřní tření, a tedy působení viskozity zanedbává a řeší 
se tangenciální neboli tečné napětí [1]. Tečné napětí můžeme řešit pro průsakovou trubici, pro dno a stěny průlomového otvoru a pro šikmý svah hráze.

\section{a) Průsaková trubice}

Pro tečné napětí byla odvozena celá řada vztahů od různých autorů, pro různé modifikace působení vody (vertikální a horizontální tečné napětí, pro vodorovný či šikmý povrch, pro opevněný či neopevněný povrch, tečné napětí od přepadajícího paprsku apod.) Nejjednodušší výpočet pro tečné napětí $\tau$ způsobené proudící vodou v průsakové trubici lze podle Darcy-Weisbacha vyjádřit podle [8] jako:

$$
\tau=\rho g \frac{D_{p}}{4} I_{E},
$$

kde $\rho$ je objemová hmotnost vody $\left[\mathrm{kg} / \mathrm{m}^{3}\right], g$ je gravitační konstanta, $D_{\mathrm{p}}$ je průměr průsakové trubice $[\mathrm{m}]$ a $I_{\mathrm{E}} \mathrm{je}$ sklon čáry energie $\mathrm{v}$ průsakové trubici [-], který se vypočítá podle [8] jako:

$$
I_{E}=\lambda \frac{L}{D_{p}} \frac{v_{p i p}^{2}}{2 g}
$$

kde $L$ je délka průsakové trubice $[\mathrm{m}] ; D_{\mathrm{p}}$ průměr průsakové trubice $[\mathrm{m}], \lambda$ je součinitel ztrát tření po délce

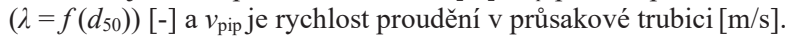

\section{b) Dno a stěny průlomového otvoru a šikmý svah hráze}

Tečné napětí $\tau$ způsobené proudící vodou na šikmém svahu podle Darcy-Weisbacha se vyjádří podle [8] jako:

$$
\tau=\rho g h_{n} \sin \alpha,
$$

kde $\rho$ je hustota vody $\left[\mathrm{kg} / \mathrm{m}^{3}\right], g$ je gravitační zrychlení, sin $\alpha$ je sklon dna pro strmé svahy a pro nízké sklony se může zaměnit za tan $\alpha \sim i_{\mathrm{w}}$, a tedy za sklon čáry energie [-] a $h_{\mathrm{n}}$ je normální hloubka na vzdušním svahu, která se vypočítá podle [8] jako:

$$
h_{n}=\left(\frac{q^{2} n^{2}}{\sin \alpha}\right),
$$

kde $q$ je jednotkový průtok $\left[\mathrm{m}^{2} / \mathrm{s}\right], n$ je drsnostní součinitel dle Manninga $\left[\mathrm{s} / \mathrm{m}^{1 / 3}\right]$ a sin $\alpha$ je sklon vzdušního svahu [-]. Pokud dojde k úplném oderodování vzdušní strany hráze, je dále průlomový otvor pouze rozšiřován do stran. Tečné napětí působící pouze do stran vychází ze vztahu přepadu přes širokou korunu následujícím vztahem [8]:

$$
\tau=\frac{\rho g^{2} n^{2}\left(h_{1}-h_{2}\right)}{h_{2}{ }^{1 / 3}},
$$

kde $h_{1}$ je hloubka před průlomovým otvorem [m n. m.] a $h_{2}$ je hloubka pod nádrží rovné $2 / 3 * h_{1}[\mathrm{~m} n$. m.].

\section{Rychlost eroze}

Výpočet eroze zemního materiálu vykazuje nejvyšší vliv při predikci hydrogramu, velikosti průlomového otvoru a času porušení. Pro výpočet rychlosti eroze zemního materiálu odvodila celá řada autorů různé vztahy založených na různých předpokladech. Většina vztahů platí pro př́pad vnitřní eroze a zároveň i v př́padě přelití. Výpočet rychlosti eroze se může lišit v závislosti na stanovení tečného napětí. V současné době všechny novodobé SW využívají pro řešení eroze kohezivních zemin vztah [m/s] [4]:

$$
\frac{d \varepsilon}{d t}=\left\{\begin{array}{cl}
k_{d}\left(\tau-\tau_{c}\right) & \text { když } \tau>\tau_{c}, \\
0 & \text { jinak }
\end{array}\right.
$$

kde $k_{\mathrm{d}}$ je koeficient erodibility [ $\mathrm{m}^{3} / \mathrm{Ns}$ ], $\tau$ tečné napětí, které je počítáno z rychlosti proudu působícího na dno a svahy $\left[\mathrm{N} / \mathrm{m}^{2}\right]$ a $\tau_{\mathrm{c}}$ kritické tečné napětí odolnosti materiálu $\left[\mathrm{N} / \mathrm{m}^{2}\right]$. Rovnice předpokládá lineární závislost mezi erodibilitou a kritickým tečným napětím.

\section{Kolaps nadloží průsakové trubice}

Kolaps nadloží průsakové trubice je důležitý jev a jeho přesnost a druh výpočtu má zásadní vliv na výsledný hydrogram a výsledný průlomový otvor. Po kolapsu nadloží dochází většinou k nejstrmějšímu nárůstu průtoku při porušení sypané hráze v důsledku vnitřní eroze. Po kolapsu nadloží přechází výpočet průtoku průsakovou trubicí (z výtoku otvorem) na výpočet přelití (přepad přes širokou korunu a eroze vzdušní strany hráze) [7].

Stabilita nadloží průsakové trubice je řešena pomocí celé řady zjednodušujících předpokladů. V př́ípadě diskretizace průlomového otvoru kruhem, lze započítat klenbový účinek. Jedním ze základních výpočtů je stanovení hmotnosti nadloží a odporových sil, s následným posouzením stability na předem stanovených smykových plochách [8] podle vztahu: 


$$
F O S=\frac{c 2 A_{t}}{W}
$$

kde $c$ je koheze zeminy [Pa], $A_{\mathrm{t}}$ svislá plocha nad okraji otvoru od otvoru až po korunu hráze vztažená k ose průsakové trubice $\left[\mathrm{m}^{2}\right]$ a $W$ je hmotnost půdy nad horní hranou průsakové trubice $\left[\mathrm{N} / \mathrm{m}^{2}\right]$.
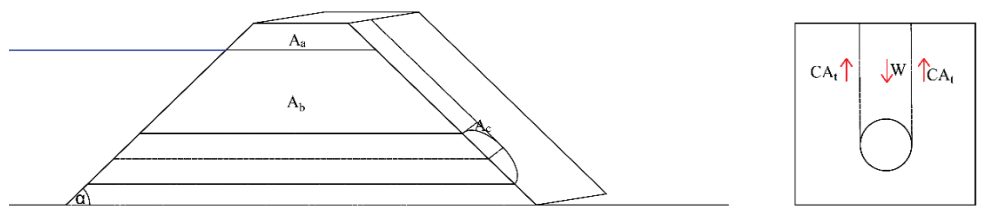

Obr. 1 Schéma ploch a sil působících při kolapsu nadloží průsakové trubice.

\section{METODIKA CITLIVOSTNÍ ANALÝZY}

Cílem citlivostní analýzy je zjisti vliv změny vstupních parametrů na změnu hledaných výstupních veličin, kde v prípadě porušení sypané hráze v důsledku vnitřní eroze (průsakovou trubicí) se jedná o určení časového průběhu průtoku $Q_{\mathrm{b}}(\mathrm{t})$ průlomovým otvorem (hypotetickou průsakovou trubicí) ve vazbě na průběh polohy $H(t)$ hladiny vody v nádrži a průměru $D(t)$ průsakové trubice čí šířce průlomového otvoru $B(t)$. Dále je pak možné softwarem definovat časové charakteristiky poruchy jako je čas iniciace poruchy a celkovou dobu trvání poruchy, čas, kdy dojde ke kolapsu stropu průsakové trubice a čas od iniciace po dosažení maximálního kulminačního průtoku.

\section{Definice základních a zjednodušujícíh předpokladů}

Proudění a vývoj průsakové cesty a průlomového otvoru jsou časově závislé proměnné. Vzhledem k obtížnosti modelování všech dějů uvnitř trubice je nutné zavést zjednodušující předpoklady. Základní zjednodušující předpoklady jsou:

- nestlačitelná kapalina (voda): hustota $\rho=$ konst.,

- izotermní proudění: neprobíhá tepelná výměna,

- konstantní viskozita kapaliny (vody) $\mu$ = konst.,

- nedochází k provzdušnění proudu kapaliny,

- konstantní, nulová př́toková rychlost povodňové vlny do nádrže: $\quad v=0$;

- jednotlivé vrstvy materiálu tělesa hráze jsou izotropní a homogenní,

- na začátku výpočtu se uvažuje zformovaná průsaková cesta v celé své délce porušení,

- předpoklad stacionarity koeficientu eroze zeminy $k_{\mathrm{d}}$, kritického tečného napětí $\tau_{\mathrm{c}}$ a drsnostního součinitele dle Manninga $n$

další předpoklady, které bývají často zanedbávány:

- vliv větrových vln na hladinu nádrže a vznik oscilačních vln,

- vliv inundačního území pod hrází na vývoj průlomového otvoru - často bývá zanedbán vlivu dolní vody na vývoj průlomového otvoru,

- nadloží průsakové trubice je po kolapsu kompletně oderodováno v jednom časovém kroku.

\section{Jednocestná citlivostní analýza}

Během této analýzy je vybrán jeden parametr, který je ,jedenkrát“"variován ze své výchozí hodnoty a je sledován, jaký má tato změna dopad na celkové výsledky výpočtu softwaru. Sledujeme tedy postupně vliv vždy jednoho parametru na sledované výstupní hodnoty. Vždy musí být změněn pouze jeden parametr, zatímco všechny ostatní zůstanou na své základní, výchozí hodnotě. Znalost odezvy matematického modelu na změnu vstupních parametrů je důležitá pro vyhodnocení použitelnosti modelu a dále informace, které vstupní parametry mají dominantní vliv na výsledné výstupy a bylo by vhodné je tedy predikovat pomocí Monte-Carlo.

Pro citlivostní analýzu byl zvolen polní test provedený v rámci projektu IMPACT v Norsku v roce 2004, který byl realizován jako rrízený experiment. Těleso hráze bylo postaveno z jílovité morénové půdy výšky $4.3 \mathrm{~m}$. Rezervoár hráze měl objem $110000 \mathrm{~m}^{3}$ při nejvyšší možné hladině $372.00 \mathrm{~m} \mathrm{n}$. m. (obr. 2). Ve spodní části tělesa hráze bylo položeno perforované potrubí DN 200, uložené v písčité zemní vrstvě $1 \mathrm{x} 1 \mathrm{~m}$, opatřené ventilem s uzávěrem [9]. 
Na začátku testu byl ventil otevřen a pískové lože bylo vypláchnuto, aby se zahájil test porušení v důsledku vnitřní eroze. Počáteční výtok z potrubí byl cca 200 1/s. Kolaps nadloží průsakové trubice je odhadován v době prudkého poklesu hladiny v nádrži tedy cca $500 \mathrm{~s}$ po začátku poruchy. Př́ímé měření času kolapsu nadloží a erozních charakteristik zeminy nebylo v rámci tesu proveditelné [9]. Vstupní parametry z polního testu IMPACT v Norsku jsou uveden v Tab. 1.

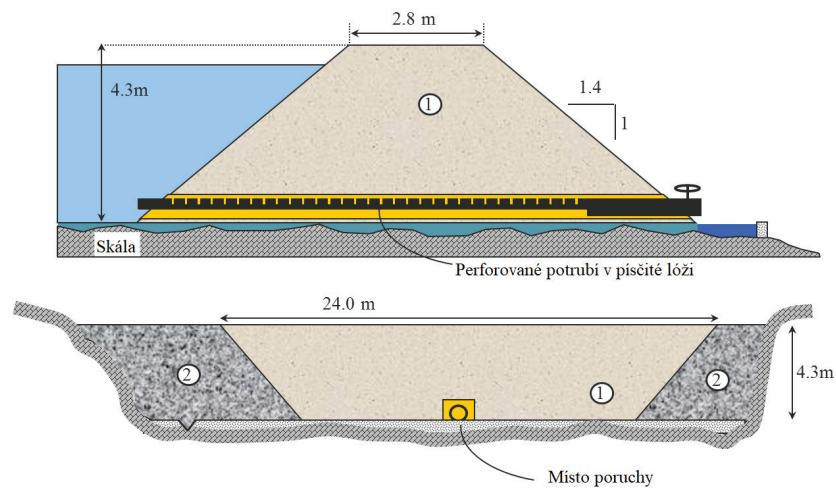

Obr. 2 Schéma polního pokusu porušení sypané hráze v důsledku vnitřní eroze v rámci projektu IMPACT v Norsku v roce 2004 [9]. 1 - Těleso hráze z morénovitých jílů, 2- zavázání hráze z rockfillu.

Tab. 1 Vstupní parametry polního pokusu porušení sypané hráze v důsledku vnitřní eroze v rámci projektu IMPACT v Norsku v roce 2004 [8], [9].

\begin{tabular}{lccc}
\hline Vstupní parametry & Zkratka & Hodnota & Jednotky \\
\hline Počáteční hladina v nádrži & $H_{0}$ & 427.28 & {$[\mathrm{~m} \mathrm{n} . \mathrm{m}]$.} \\
Nadmořská výška koruny hráze & $C_{\mathrm{L}}$ & 427.5 & {$[\mathrm{~m} \mathrm{n} . \mathrm{m}]$.} \\
Výška hráze & $H_{\mathrm{H}}$ & 4.3 & {$[\mathrm{~m}]$} \\
Š́řka koruny hráze & $C_{\mathrm{w}}$ & 2.8 & {$[\mathrm{~m}]$} \\
Délka hráze & $L_{\mathrm{H}}$ & 24 & {$[\mathrm{~m}]$} \\
Nadmořská výška skalního podloží & $H_{\mathrm{p}}$ & 423 & {$[\mathrm{~m} \mathrm{n} . \mathrm{m}]$.} \\
Sklon návodního svahu & $1: \mathrm{X}$ & $01: 01.4$ & {$[\mathrm{~V}: \mathrm{H}]$} \\
Sklon vzdušního svahu & $1: \mathrm{X}$ & $01: 01.4$ & {$[\mathrm{~V}: \mathrm{H}]$} \\
Počáteční výška výtoku z průsak. trubice & $H_{\mathrm{out}}$ & 364.81 & {$[\mathrm{~m} \mathrm{n} . \mathrm{m}]$.} \\
Počáteční výška osy průsak. trubice & $H_{\mathrm{osa}}$ & 364.81 & {$[\mathrm{~m} \mathrm{n} . \mathrm{m}]$.} \\
Počáteční průměr průsakové trubice & $D_{0}$ & 0.2 & {$[\mathrm{~m}]$} \\
Přepadový koeficient & $m$ & 0.33 & {$[-]$} \\
Velikost zrna $d_{50}$ & $d_{50}$ & $7-\mathrm{Jun}$ & {$[\mathrm{mm}]$} \\
Objemová hmotnost zeminy suché & $\rho_{\mathrm{d}}$ & 2090 & {$\left[\mathrm{~kg} / \mathrm{m}^{3}\right]$} \\
Koheze & $c^{\prime}$ & 20 & {$\left[\mathrm{kN} / \mathrm{m}^{2}\right]$} \\
Procenta jílu & $P$ & 2 & {$[\%]$} \\
Index plasticity & $P I$ & Netestováno & {$[-]$} \\
Úhel vnitřního tření & $\varphi$ & 45.6 & {$\left[{ }^{\circ}\right]$} \\
Kritické tečné nap̌̌tí & $\tau_{\mathrm{c}}$ & Netestováno & {$\left[\mathrm{N} / \mathrm{m}^{2}\right]$} \\
Koeficient erodibility & $k_{\mathrm{d}}$ & Netestováno & {$\left[\mathrm{m}^{3} / \mathrm{Ns}\right]$} \\
Pórovitost & $p$ & 0.245 & {$[-]$} \\
\hline
\end{tabular}

Pro citlivostní analýzu se vybraly vstupní parametry vlastností zemin polního testu uvedené v Tab. 1, pro které byla sledována citlivost SW AREBA. Tyto parametry byly snižovány a zvyšována $\mathrm{v}$ intervalu $20 \%$ a $40 \%$ uvedené v Tab. 2. 
Tab. 2 Parametry sledované v rámci citlivostní analýzy SW AREBA.

\begin{tabular}{lcccccc}
\hline $\begin{array}{c}\text { Vstupní parametry pro } \\
\text { citlivostní analýzu }\end{array}$ & Jednotky & $\begin{array}{c}\mathbf{6 0} \% \\
\text { vstupní } \\
\text { hodnoty }\end{array}$ & $\begin{array}{c}\mathbf{8 0} \% \\
\text { vstupní } \\
\text { hodnoty }\end{array}$ & $\begin{array}{c}\text { Vstupní } \\
\text { hodnoty }\end{array}$ & $\begin{array}{c}\mathbf{1 2 0} \% \\
\text { vstupní } \\
\text { hodnoty }\end{array}$ & $\begin{array}{c}\mathbf{1 4 0} \% \\
\text { vstupní } \\
\text { hodnoty }\end{array}$ \\
\hline Drsnost dle Manninga $-n$ & $\mathrm{~s} / \mathrm{m}^{1 / 3}$ & 0.022 & 0.029 & 0.036 & 0.043 & 0.05 \\
Kritické tečné napětí $-\tau_{\mathrm{c}}$ & $\mathrm{N} / \mathrm{m}^{2}$ & 3.41 & 4.544 & 5.68 & 6.82 & 7.95 \\
Koeficient eroze $-k_{\mathrm{d}}$ & $\mathrm{m}^{3} / \mathrm{Ns}$ & 10.61 & 14.14 & 17.68 & 21.22 & 24.75 \\
Pórovitost $-p$ & & 0.147 & 0.196 & 0.245 & 0.294 & 0.343 \\
Průměrné zrno $-d_{50}$ & $\mathrm{~m}$ & 0.0039 & 0.0052 & 0.0065 & 0.0078 & 0.0091 \\
Vnitřní úhel tření zeminy $-\phi$ & $\circ$ & 27.36 & 36.48 & 45.6 & 54.72 & 63.84 \\
\hline
\end{tabular}

\section{VÝSLEDKY}

Pro vybraný SW AREBA popsaný v kapitole 2, byly provedeny simulace zvoleného experimentu v rozsahu všech hodnot popsaných v kapitole 4 pomocí jednocestné citlivostní analýzy. Z výsledků jednocestné analýzy je patrné, že změny parametrů pórovitosti $p$, průměrného zrna zeminy $d_{50}$, vnitřního úhlu tření zeminy $\phi$ a kritického tečného napětí $\tau_{\mathrm{c}}$ mají minimální vliv na sledovaný maximální průlomový průtok, velikost průlomového otvoru ani na čas porušení (obr.3).
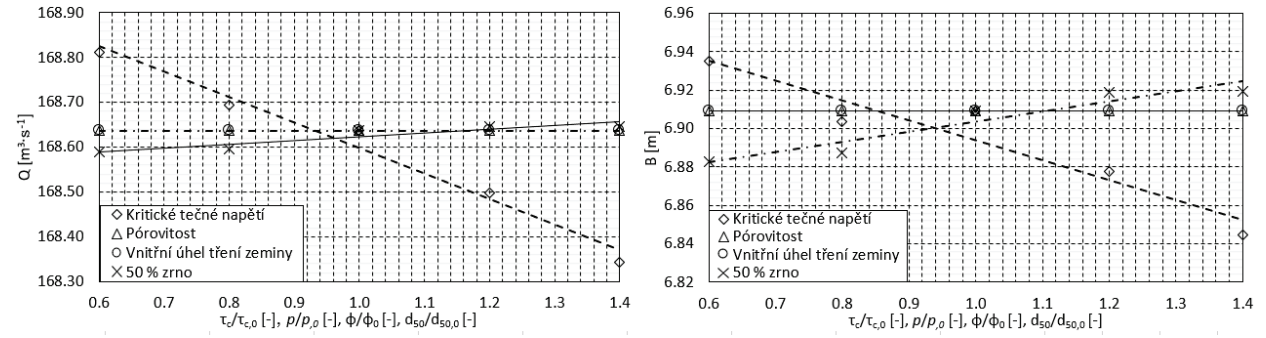

Obr. 3 Graf výsledků citlivostní analýzy parametrů nejvíce ovlivňujících sledované výsledné veličiny. Vliv na velikost průlomového otvoru (vpravo) a vliv na velikost průlomového průtoku (vlevo).

Z výsledků jednocestné citlivostní analýzy vyplývá, že SW AREBA je citlivý při volbě koeficientu erodibility $k_{\mathrm{d}}$ vstupující do výpočtu eroze zeminy a drsnostního součinitele dle Manninga n vstupujícího do výpočtu tečného napětí $\tau$. Významné parametry ovlivňující sledované výsledné veličiny a jejich procentuální odchylky od vstupního výsledku jsou uvedeny v Tab. 3, Tab. 4 a na Obr. 4.

Tab. 3 Významný parametr ovlivňující sledované výsledné veličiny a jejich procentuální odchylky od vstupního výsledku - drsnostní součinitel dle Manninga $n$.

\begin{tabular}{cccccc}
\hline Parametr & $\begin{array}{c}\text { Vstupní } \\
\text { hodnoty }\end{array}$ & $\begin{array}{c}\mathbf{6 0} \% \text { vstupní } \\
\text { hodnoty }\end{array}$ & $\begin{array}{c}\mathbf{8 0} \% \text { vstupní } \\
\text { hodnoty }\end{array}$ & $\begin{array}{c}\mathbf{1 2 0} \% \text { vstupní } \\
\text { hodnoty }\end{array}$ & $\begin{array}{c}\mathbf{1 4 0} \% \text { vstupní } \\
\text { hodnoty }\end{array}$ \\
\hline$Q\left[\mathrm{~m}^{3} / \mathrm{s}\right]$ & 168.64 & 143.36 & 155.02 & 173.22 & 167.23 \\
$Q_{\mathrm{v}} / Q$ & $100 \%$ & $85 \%$ & $92 \%$ & $102.75 \%$ & $99.16 \%$ \\
$T_{\mathrm{p}}[\mathrm{s}]$ & 2007 & 2108 & 2044 & 1951 & 1920 \\
$T_{\mathrm{pv}} / T_{\mathrm{p}}$ & $100 \%$ & $105.03 \%$ & $101.84 \%$ & $97.21 \%$ & $95.67 \%$ \\
$B[\mathrm{~m}]$ & 6.91 & 4.11 & 5.36 & 8.74 & 10.66 \\
$B_{\mathrm{v}} / B$ & $100 \%$ & $59.48 \%$ & $77.57 \%$ & $126.47 \%$ & $154.27 \%$ \\
\hline
\end{tabular}

Tab. 4 Významný parametr ovlivňující sledované výsledné veličiny a jejich procentuální odchylky od vstupního výsledku - koeficient erodibility $k_{\mathrm{d}}$.

\begin{tabular}{cccccc}
\hline Parametr & $\begin{array}{c}\text { Vstupní } \\
\text { hodnoty }\end{array}$ & $\begin{array}{c}\mathbf{6 0} \% \text { vstupní } \\
\text { hodnoty }\end{array}$ & $\begin{array}{c}\mathbf{8 0} \text { \% vstupní } \\
\text { hodnoty }\end{array}$ & $\begin{array}{c}\mathbf{1 2 0} \% \text { vstupní } \\
\text { hodnoty }\end{array}$ & $\begin{array}{c}\mathbf{1 4 0} \% \text { vstupní } \\
\text { hodnoty }\end{array}$ \\
\hline$Q\left[\mathrm{~m}^{3} / \mathrm{s}\right]$ & 168.64 & 152.00 & 158.87 & 170.21 & 172.14 \\
$Q_{\mathrm{v}} / Q$ & $100 \%$ & $90.13 \%$ & $94.21 \%$ & $100.93 \%$ & $101.95 \%$
\end{tabular}




\begin{tabular}{cccccc}
$T_{\mathrm{p}}[\mathrm{s}]$ & 2007 & 2061 & 2049 & 1967 & 1956 \\
$T_{\mathrm{pv}} / T_{\mathrm{p}}$ & $100 \%$ & $102.69 \%$ & $102.09 \%$ & $98.01 \%$ & $97.46 \%$ \\
$B[\mathrm{~m}]$ & 6.91 & 4.96 & 5.82 & 7.52 & 8.37 \\
$B_{\mathrm{v}} / B$ & $100 \%$ & $71.78 \%$ & $84.23 \%$ & $108.83 \%$ & $121.13 \%$ \\
\hline
\end{tabular}
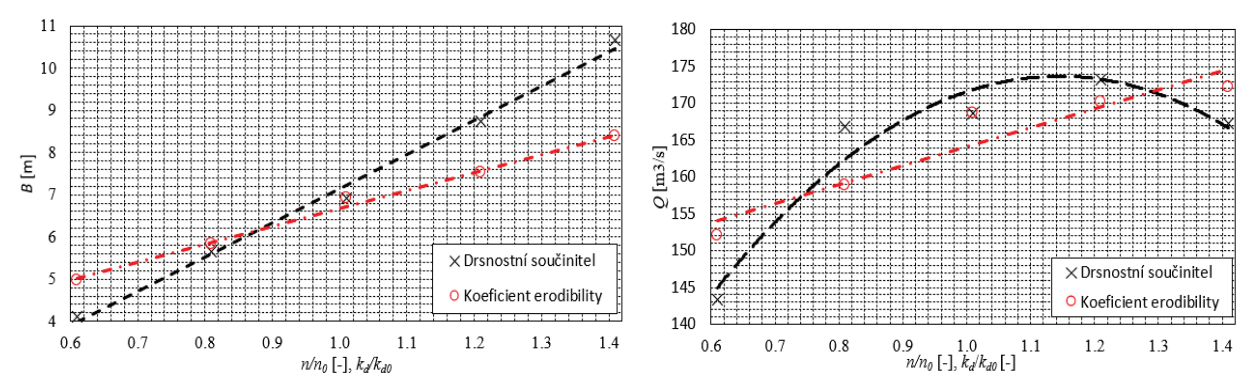

Obr. 4 Graf výsledků citlivostní analýzy parametrů nejvíce ovlivňujících sledované výsledné veličiny. Vliv na velikost průlomového otvoru (vlevo) a vliv na velikost průlomového průtoku (vpravo).

V prrípadě vlivu drsnostního součinitel dle Manninga $n$ na vývoj šiřky průlomového otvoru lze konstatovat, že vliv má konstantní pozitivní lineární gradient. Př́i nižších hodnotách drsnostního součinitele dochází k marginálnímu poklesu výsledné velikosti průlomového otvoru. V př́padě snížení drsnostního součinitele o 20 či $40 \%$ dojde ke snížení velikosti průlomového úměrně, a to o cca $20 \%$ a $40 \%$.

Vliv na velikost průlomového průtoku mají hlavně nižší hodnoty drsnostního součinitele v intervalu od cca 0.016 - 0.035. Při vyšších hodnotách drsnostního součinitele není vliv na průtok marginální a dochází dokonce ke snižování průlomového průtoku $\pm 3 \%$. Vliv součinitele drsnosti při vyšších hodnotách se projevuje pouze ve velikosti průlomového otvoru.

Koeficient erodibility má v př́padě vyhodnocení vlivu na velikost průlomového otvoru lineární pozitivní gradient, avšak s nižším sklonem než v př́padě drsnostního součinitele. Lze tedy konstatovat že vliv na velikost průlomového otvoru není tak marginální jako v př́ípadě drsnostního součinitele, a to o cca $10 \%$.

Vliv na velikost průlomového průtoku mají hlavně nižší hodnoty koeficientu erodibility, kde je nárůst průtoku lineárně strmější než v případě vyšších hodnot koeficientu erodibility. Při vyšších hodnotách koeficientu erodibility je změna průtoku $\pm 6 \%$.

\section{DISKUZE A ZÁVĚR}

Tento př́spěvek měl za cíl popsat SW AREBA a provést jednocestnou citlivostní analýzu. Z analytické analýzy SW AREBA bylo zjištěno, že se s drsnostním součinitelem dle Manninga a s koeficientem erodibility uvažuje konstantním po celou délku simulace. Řešením by bylo $\mathrm{v}$ prrípadě drsnostního součinitel dle Manninga $n$ zapracování do SW výpočet drsnostního součinitele v čase v závislosti na hloubce či hydraulickém poloměru podle např. Mattase [5] apod. Pro př́pad výpočtu vnitřní eroze se doporučuje nižší koeficient erodibility a po kolapsu nadloží průsakové trubice pro př́pad přelití koeficient úměrně zvýšit, jelikož eroze je rychlejší než v př́padě vnitřní eroze. Tohoto předpokladu lze také dosáhnout úměrným zvýšením či snížením drsnostního součinitele, při konstantní hodnotě koeficientu erodibility.

Z citlivostní analýzy vyplývá, že v př́padě změny parametrů zeminy pórovitosti $p$, průměrného zrna zeminy $d_{50}$, vnitřního úhlu tření zeminy $\phi$ a kritického tečného napětí nemají prakticky vliv na sledované výstupní hodnoty (Obr. 3) a lze je tedy do programu zadat deterministicky, metodou podobnosti vlastností zemin např. z [2], kde je uvedena celosvětová databáze vzorků zemin a jejich naměřené vlastnosti. $V$ mnoha př́padech je zde uvedena i míra eroze zeminy, pro kterou lze následně odvodit interval hodnot koeficientu erodibility. Parametr erodibility a koeficientu drsnostního součinitele dle Manninga se doporučuje do SW AREBA zadat v intervalu hodnot a provést mnohonásobné simulace pomocí metody Monte-Carlo.

\section{Poděkování}

Př́spěvek byl vytvořen v rámci řešení projektu juniorského specifického výzkumu FAST-J-21-7486 - Citlivostní analýza parametrů vstupující do modelů porušení sypaných hrází v důsledku vnitřní eroze a v rámci disertační práce. 


\section{Použité zdroje}

[1] BOOR, B.; KUNŠTÁTSKÝ, J.; PATOČKA, C. (1968): Hydraulika pro vodohospodářské stavby. SNTL - Nakladatelství technické literatury, Praha, $520 \mathrm{~s}$.

[2] BRIAUD, J., L.; SHAFII, I.; CHEN, H., CH.; MEDINA-CETINA, Z. (2019): Relationship Between Erodibility and Properties of Soils. NCHRP Research report 915. National Academies of Sciences, Engineering, and Medicine 2019. Washington, DC: The National Academies Press, 339 str.

[3] GOFF, C. (2014): Small reservoirs simplified risk assessment methodology. Research modelling report, project FD2658, MCR5053-RT002-R03-00, $35 \mathrm{~s}$.

[4] HANSON, G., J.; SIMON, A. (2001): Erodibility of cohesive streambeds in the loess area of the midwestern USA. Hydrological Processes, 2001, 15, s. 23-38.

[5] MATTAS, D.; PETRŮJOVÁ, T.; MAREŠ, K. (1998): Pohyb sedimentů v podélném profilu toku. Závěrečná zpráva DÚ02 projektu VaV/510/2/96. VÚV T.G.M. Praha

[6] MOHAMED, M., A., A. (2002): Embankment breach formation and modelling methods. Ph.D. Thesis, The Open University, England.

[7] SINGH, V., P. (1996): Dam Breach Modeling Technology. Louisiana State University, Kluwer Academic Publishers, Baton Rouge, USA, Dodrecht, $242 \mathrm{~s}$.

[8] VAN DAMME, M.; MORRIS, M., W.; HASSAN, M., A., A., M. (2012): A new approach to rapid assessment of breach driven embankment failures. FRMRC Research Report, WP4.4, 2012.

[9] VASKINN, K., A.; LOVOLL, A.; MORRIS, M.; HASSAN M., A., A., M. Physical modelling of Breach formation: Large scale field test. IMPACT project, 〈www.floodsite.net〉, 2004. 